\title{
Probing the Lewis acidity of heavier pnictogen trichlorides
}

\author{
JOBHA A JOHNSON and AJAY VENUGOPAL* (D) \\ School of Chemistry, Indian Institute of Science Education and Research Thiruvananthapuram, \\ Vithura, Thiruvananthapuram 695 551, Kerala, India \\ E-mail: venugopal@iisertvm.ac.in
}

MS received 19 October 2019; accepted 25 October 2019; published online 3 December 2019

\begin{abstract}
Lewis acidity of $\mathrm{SbCl}_{3}$ and $\mathrm{BiCl}_{3}$ has been investigated in the solid as well as in solution state. Two $\beta$-ketoimine ligands, $[\mathrm{O}=\mathrm{C}(\mathrm{Me})] \mathrm{CH}[\mathrm{C}(\mathrm{Me}) \mathrm{NHAr}]$ (L1, $\mathrm{Ar}=2,6$-diisopropylphenyl) and $\left[\left(\mathrm{CH}_{2}\right)_{2}\{-\right.$ $\left.\mathrm{N}(\mathrm{H}) \mathrm{C}(\mathrm{Me}) \mathrm{CHC}(\mathrm{Me})=\mathrm{O}_{2}\right] \quad(\mathbf{L 2})$ are used to prepare the complexes $\left[(\mathbf{L 1})(\mathrm{THF}) \mathrm{SbCl}_{3}\right]_{2} \quad(\mathbf{1})$, $\left[(\mathbf{L 1})(\mathrm{THF}) \mathrm{BiCl}_{3}\right]_{2}(\mathbf{2}),\left[\mathbf{L} 2 \mathrm{SbCl}_{3}\right]_{2}(\mathbf{3})$ and $\left[(\mathbf{L 2})_{3}\left(\mathrm{BiCl}_{3}\right)_{2}\right](\mathbf{4})$, which are characterized by multinuclear NMR spectroscopy, elemental analysis and single-crystal X-ray diffraction experiments. Solid-state structural analysis of 1-4 and solution studies on $\mathrm{SbCl}_{3}$ and $\mathrm{BiCl}_{3}$ using the Gutmann-Beckett method reveal the higher Lewis acidity of $\mathrm{BiCl}_{3}$ compared to $\mathrm{SbCl}_{3}$.
\end{abstract}

Keywords. Pnictogen elements; Lewis acidity; $\beta$-ketoiminato ligands; Gutmann-Beckett method.

\section{Introduction}

Salts of heavier pnictogens (Pn), antimony and bismuth in +3 oxidation state are employed as Lewis acids in organic synthesis. ${ }^{1}$ Common examples of these salts include chlorides, carboxylates and trifluoromethanesulfonate. A qualitative model for the origin of Lewis acidity in $\mathrm{Sb}$ (III) and $\mathrm{Bi}$ (III) compounds was proposed by Norman in $1994 .^{2}$ According to this model, a polarized $\mathrm{Pn}-\mathrm{X}$ bond has a corresponding low lying antibonding $\sigma^{*}$-orbital that can accept a pair of electrons. The $\mathrm{Pn}-\mathrm{X}$ bonds constitute the primary bonds, while the interaction between antibonding orbitals and Lewis bases constitute the secondary bonding. The energy levels of the antibonding orbitals and hence, Lewis acidity of $\mathrm{PnX}_{3}$ is dependent on the extent of polarization in primary bonds. We have recently used this model to explain the Lewis acidity in cationic bismuth complexes. ${ }^{3-5}$ The cationic $\left[\left(\mathrm{Me}_{2} \mathrm{NC}_{6} \mathrm{H}_{4}\right)(\mathrm{Mesityl}) \mathrm{Bi}\right]^{+}$bears one $\sigma^{*}$-orbital and the dicationic tri-coordinate [tris(2,5-dimethylpyrazolylborate)bismuth(III) $]^{2+}$ bears two $\pi^{*}$ - and one $\sigma^{*}$ orbitals. These anti-bonding orbitals exhibit remarkable Lewis acidity and can be employed for olefin hydrosilylation. ${ }^{4}$ While there are few reports where Lewis acidity in $\mathrm{Sb}$ (III) and $\mathrm{Bi}(\mathrm{III})$ compounds has been explored, Lewis acidity of simple salts like $\mathrm{SbCl}_{3}$ and $\mathrm{BiCl}_{3}$ is not well-quantified. ${ }^{6}$ In this work, we

*For correspondence have attempted to compare the Lewis acidity of $\mathrm{SbCl}_{3}$ and $\mathrm{BiCl}_{3}$ by the solid-state structure as well as solution studies. $\beta$-Ketoimine adducts of these salts have been prepared and structure elucidation done by single-crystal X-ray diffraction studies are used to study the Lewis acidity in the solid-state. Lewis acidity of $\mathrm{SbCl}_{3}$ and $\mathrm{BiCl}_{3}$ have been probed in solution by performing the Gutmann-Beckett test. ${ }^{7}$

\section{Experimental}

General methods: All manipulations were performed in a nitrogen/argon atmosphere using standard Schlenk and glovebox techniques. The solvents used for the synthesis and NMR experiments were dried, distilled, and degassed prior to use by standard methods. The distilled solvents were stored over appropriate drying agents. $[\mathrm{O}=\mathrm{C}(\mathrm{Me})] \mathrm{CH}[\mathrm{C}(\mathrm{Me}) \mathrm{NHAr}]^{8}$ and $\left[\left(\mathrm{CH}_{2}\right)_{2}\{-\right.$ $\left.\mathrm{N}(\mathrm{H}) \mathrm{C}(\mathrm{Me}) \mathrm{CHC}(\mathrm{Me})=\mathrm{O}_{2}\right]^{9}$ were prepared according to the literature procedures. Anhydrous $\mathrm{SbCl}_{3}$ and $\mathrm{BiCl}_{3}$ were purchased from Sigma-Aldrich and used as such without any further purification. NMR measurements were performed with a Bruker $500 \mathrm{MHz}$ spectrometer. Elemental analysis was performed with an Elemental Vario Micro Cube. Single-crystal X-ray diffraction experiments were performed on a Bruker Kappa Apex-II CCD diffractometer using Mo-Ka source $(\lambda=0.71073 \AA)$. The structures were solved by direct methods with SIR-92 and SHELX-2014. ${ }^{10}$ 
Crystallographic data and structure refinement results are summarized in Table 1.

Synthesis of 1: THF (20 mL) was condensed on to a mixture of $([\mathrm{O}=\mathrm{C}(\mathrm{Me})] \mathrm{CH}[\mathrm{C}(\mathrm{Me}) \mathrm{NHAr}])(1 \mathrm{mmol}$, $0.260 \mathrm{~g})$ and $\mathrm{SbCl}_{3}(1 \mathrm{mmol}, 0.228 \mathrm{~g})$ at $-196{ }^{\circ} \mathrm{C}$. The reaction mixture was stirred at room temperature for $12 \mathrm{~h}$. Addition of excess $n$-pentane to the reaction mixture and storage of the resultant solution at $-30{ }^{\circ} \mathrm{C}$ afforded crystalline precipitate of $\mathbf{1}(0.45 \mathrm{~g}, 92 \%) ;{ }^{1} \mathrm{H}$ NMR $\left(500 \mathrm{MHz}, \mathrm{THF}-\mathrm{D}_{8}\right): \delta 1.11\left(\mathrm{~d},{ }^{3} J_{\mathrm{H}-\mathrm{H}}=5 \mathrm{~Hz}\right.$, $\left.6 \mathrm{H}, \mathrm{CH}\left(\mathrm{CH}_{3}\right)_{2}\right), \delta 1.21\left(\mathrm{~d},{ }^{3} J_{\mathrm{H}-\mathrm{H}}=5 \mathrm{~Hz}, 6 \mathrm{H}\right.$, $\left.\mathrm{CH}\left(\mathrm{CH}_{3}\right)_{2}\right), \delta 1.60\left(\mathrm{~s}, 3 \mathrm{H}, \mathrm{CH}_{3} \mathrm{C}(\mathrm{NH})\right), \delta 2.00(\mathrm{~s}, 3 \mathrm{H}$, $\left.\mathrm{CH}_{3} \mathrm{C}(\mathrm{O})\right), \delta 3.00-3.08\left(\mathrm{~m}, 2 \mathrm{H}, \mathrm{CH}\left(\mathrm{CH}_{3}\right)_{2}\right), \delta 5.20$ (s, $\left.1 \mathrm{H}, \mathrm{CH}_{3} \mathrm{C}(\mathrm{NH}) \mathrm{CH}\right), \delta 7.18-7.30\left(\mathrm{~m}, 3 \mathrm{H}, \mathrm{C}_{6} H_{3}\right)$, $\delta 12.19(\mathrm{~s}, 1 \mathrm{H}, \mathrm{NH}) \mathrm{ppm} ;{ }^{13} \mathrm{C}$ NMR $(126 \mathrm{MHz}$, THF$\left.\mathrm{D}_{8}\right): \delta 19.31\left(\mathrm{CH}_{3}\right), \delta 23.03\left(\mathrm{CH}\left(\mathrm{CH}_{3}\right)_{2}\right), \delta 25.03$ $\left(\mathrm{CH}\left(\mathrm{CH}_{3}\right)_{2}\right), \delta 29.04\left(\mathrm{CH}_{3}\right), \delta 29.56\left(\mathrm{CH}\left(\mathrm{CH}_{3}\right)_{2}\right)$, $\delta \quad 96.18((\mathrm{CNH}) C \mathrm{H}(\mathrm{CO})), \delta \quad 124.43 \quad\left(m-\mathrm{CH}_{\mathrm{N}-\text { aryl }}\right)$, $\delta 129.16\left(p-C \mathrm{H}_{\mathrm{N}-\text { aryl }}\right), \delta 134.98\left(o-\mathrm{CH}_{\mathrm{N}-\text { aryl }}\right), \delta 147.34$ $\left(C_{\mathrm{N} \text {-aryl }}\right), \quad \delta \quad 163.25 \quad\left(C(\mathrm{NH})\left(\mathrm{CH}_{3}\right)\right), \quad \delta \quad 195.77$ $\left(\mathrm{CO}\left(\mathrm{CH}_{3}\right)\right)$ ppm; Elemental analysis $(\%)$ for $\mathrm{C}_{17} \mathrm{H}_{25}$ $\mathrm{NOSbCl}_{3}$ : Calculated: C 68.64, H 8.13, N 4.71, Found: C 68.62, H 8.14, N 4.71

Synthesis of 2: THF (20 mL) was condensed on to a mixture of $([\mathrm{O}=\mathrm{C}(\mathrm{Me})] \mathrm{CH}[\mathrm{C}(\mathrm{Me}) \mathrm{NHAr}])(1 \mathrm{mmol}$, $0.260 \mathrm{~g})$ and $\mathrm{BiCl}_{3}(1 \mathrm{mmol}, 0.315 \mathrm{~g})$ at $-196{ }^{\circ} \mathrm{C}$. The reaction mixture was stirred at room temperature. After $12 \mathrm{~h}$ it was filtered and concentrated. The concentrated THF solution stored at $-30{ }^{\circ} \mathrm{C}$ gave crystals of $2(0.52 \mathrm{~g}, 90 \%) .{ }^{1} \mathrm{H}$ NMR $(500 \mathrm{MHz}$, $\left.\mathrm{THF}_{8}\right): \delta 1.11\left(\mathrm{~d},{ }^{3} J_{\mathrm{H}-\mathrm{H}}=10 \mathrm{~Hz}, 6 \mathrm{H}, \mathrm{CH}\left(\mathrm{CH}_{3}\right)_{2}\right)$, $\delta 1.21\left(\mathrm{~d},{ }^{3} J_{\mathrm{H}-\mathrm{H}}=10 \mathrm{~Hz}, 6 \mathrm{H}, \mathrm{CH}\left(\mathrm{CH}_{3}\right)_{2}\right), \delta 1.60(\mathrm{~s}$, $\left.3 \mathrm{H}, \quad \mathrm{CH}_{3} \mathrm{C}(\mathrm{NH})\right), \delta 2.00\left(\mathrm{~s}, 3 \mathrm{H}, \mathrm{CH}_{3} \mathrm{C}(\mathrm{O})\right)$, $\delta$ 3.00-3.08 (m, $\left.2 \mathrm{H}, \mathrm{CH}\left(\mathrm{CH}_{3}\right)_{2}\right), \delta 5.20(\mathrm{~s}, 1 \mathrm{H}$, $\left.\mathrm{CH}_{3} \mathrm{C}(\mathrm{NH}) \mathrm{CH}\right), \delta 7.18-7.30\left(\mathrm{~m}, 3 \mathrm{H}, \mathrm{C}_{6} \mathrm{H}_{3}\right), \delta 12.18$ (s, 1H, NH) ppm; ${ }^{13} \mathrm{C}$ NMR (126 MHz, THF-D 8 ): $\delta \quad 19.31 \quad\left(\mathrm{CH}_{3}\right), \quad \delta \quad 23.03 \quad\left(\mathrm{CH}\left(\mathrm{CH}_{3}\right)_{2}\right), \quad \delta \quad 25.02$ $\left(\mathrm{CH}\left(\mathrm{CH}_{3}\right)_{2}\right), \delta 29.07\left(\mathrm{CH}_{3}\right), \delta 29.56\left(\mathrm{CH}\left(\mathrm{CH}_{3}\right)_{2}\right)$, $\delta 96.20((\mathrm{CNH}) \mathrm{CH}(\mathrm{CO})), \delta \quad 124.44 \quad\left(m-\mathrm{CH}_{\mathrm{N} \text {-aryl }}\right)$, $\delta 129.16\left(p-\mathrm{CH}_{\mathrm{N} \text {-aryl }}\right), \delta 134.98\left(o-C \mathrm{H}_{\mathrm{N} \text {-aryl }}\right), \delta 147.36$ $\left(C_{\mathrm{N} \text {-aryl }}\right), \quad \delta \quad 163.32 \quad\left(C(\mathrm{NH})\left(\mathrm{CH}_{3}\right)\right), \quad \delta \quad 195.78$ $\left(\mathrm{CO}\left(\mathrm{CH}_{3}\right)\right)$ ppm; Elemental analysis $(\%)$ for $\mathrm{C}_{17} \mathrm{H}_{25}$ $\mathrm{NOBiCl}_{3}$ : Calculated: $\mathrm{C}$ 35.53, $\mathrm{H}$ 4.38, N 2.44, Found: C 35.52, H 4.39, N 2.46.

Synthesis of 3: THF (20 mL) was condensed on to a mixture of $\left(\left[\left(\mathrm{CH}_{2}\right)_{2}\{\mathrm{~N}(\mathrm{H}) \mathrm{C}(\mathrm{Me}) \mathrm{CHC}(\mathrm{Me})=\mathrm{O}\}_{2}\right]\right)$ $(1 \mathrm{mmol}, 0.224 \mathrm{~g})$ and $\mathrm{SbCl}_{3}(1 \mathrm{mmol}, 0.228 \mathrm{~g})$ at $-196{ }^{\circ} \mathrm{C}$. The reaction mixture was stirred at room temperature for $12 \mathrm{~h}$. The turbid reaction mixture was filtered and layered with $n$-pentane resulting in crystals of $3(0.41 \mathrm{~g}, 90 \%)$. ${ }^{1} \mathrm{H}$ NMR (500 MHz, THF-D 8 ): $\delta 1.87\left(\mathrm{~s}, 6 \mathrm{H}, \mathrm{CH}_{3} \mathrm{CN}\right), \delta 1.89\left(\mathrm{~s}, 6 \mathrm{H}, \mathrm{CH}_{3} \mathrm{CO}\right)$, $\delta 3.42$ (s(br), $\left.4 \mathrm{H}, \mathrm{CH}_{2}\right), \delta 4.91$ (s, $\left.2 \mathrm{H}, \mathrm{CH}\right), \delta 10.93$ (s, $2 \mathrm{H}, \mathrm{NH}) \mathrm{ppm} ;{ }^{13} \mathrm{C}$ NMR $\left(126 \mathrm{MHz}, \mathrm{THF}-\mathrm{D}_{8}\right)$ : $\delta 18.78\left(\mathrm{CH}_{3}\right), \delta 28.84\left(\mathrm{CH}_{3}\right), \delta 44.44\left(\left(\mathrm{CH}_{2}\right), \delta 96.17\right.$ $(\mathrm{CH}), \delta 163.65\left(\mathrm{CH}_{3} \mathrm{CN}\right), \delta 194.64\left(\mathrm{CH}_{3} \mathrm{CO}\right) \mathrm{ppm} ;$

Table 1. Crystallographic data, details of data collection, and structure refinement parameters for compounds 1-4.

\begin{tabular}{|c|c|c|c|c|}
\hline & 1 & 2 & 3 & 4 \\
\hline Empirical formula & $\mathrm{C}_{21} \mathrm{H}_{33} \mathrm{Cl}_{3} \mathrm{NO}_{2} \mathrm{Sb}$ & $\mathrm{C}_{21} \mathrm{H}_{33} \mathrm{Cl}_{3} \mathrm{NO}_{2} \mathrm{Bi}$ & $\mathrm{C}_{12} \mathrm{H}_{20} \mathrm{Cl}_{3} \mathrm{~N}_{2} \mathrm{O}_{2} \mathrm{Sb}$ & $\mathrm{C}_{36} \mathrm{H}_{60} \mathrm{Bi}_{2} \mathrm{Cl}_{6} \mathrm{~N}_{6} \mathrm{O}_{6}$ \\
\hline Formula weight $\left[\mathrm{gmol}^{-1}\right]$ & 559.58 & 1291.61 & 1291.61 & 1303.56 \\
\hline Temperature $[\mathrm{K}]$ & $150(2)$ & $296(2)$ & $150(2)$ & $150(2)$ \\
\hline Crystal system & Monoclinic & Triclinic & Triclinic & Triclinic \\
\hline Space group & $\mathrm{P} 2{ }_{1} / \mathrm{c}$ & $\mathrm{P} \overline{1}$ & $\mathrm{P} \overline{1}$ & $\mathrm{P} \overline{1}$ \\
\hline$a[\AA]$ & 10.259 & $10.3167(7)$ & $8.0941(3)$ & $9.2239(11)$ \\
\hline$b[\AA]$ & 16.204 & $15.4216(11)$ & $9.5066(3)$ & $9.3247(12)$ \\
\hline$c[\AA]$ & 15.480 & $25.3050(18)$ & $12.2441(5)$ & $16.723(2)$ \\
\hline$\alpha\left[^{\circ}\right]$ & 90 & $88.924(2)$ & $103.073(2)$ & $97.800(6)$ \\
\hline$\beta\left[^{\circ}\right]$ & 104.92 & $86.809(2)$ & $95.752(2)$ & $92.674(6)$ \\
\hline$\gamma\left[^{\circ}\right]$ & 90 & $71.979(2)$ & $108.129(2)$ & $107.100(5)$ \\
\hline Volume $\left[\AA^{3}\right]$ & 2486.5 & $3822.6(5)$ & $857.24(6)$ & $1356.4(3)$ \\
\hline $\mathrm{Z}$ & 4 & 3 & 2 & 1 \\
\hline Calculated density $\left[\mathrm{mgm}^{-3}\right]$ & 1.495 & 1.683 & 1.753 & 1.596 \\
\hline$\theta$ range $\left[{ }^{\circ}\right]$ & 2.409 to 24.997 & 0.806 to 25.000 & 2.508 to 24.997 & 2.526 to 25.000 \\
\hline Reflections collecte & 33101 & 96181 & 12496 & 20130 \\
\hline Independent reflections $\left(R_{\text {int }}\right)$ & $4377(0.0352)$ & $13452(0.1056)$ & $3019(0.0246)$ & $4763(0.0300)$ \\
\hline Data/restraints/parameters & $4377 / 0 / 259$ & $13452 / 67 / 803$ & $3019 / 0 / 185$ & $4763 / 2 / 253$ \\
\hline Goodness-of-fit on $F^{2}$ & 1.058 & 1.040 & 1.047 & 1.052 \\
\hline $\mathrm{R} 1, w \mathrm{R} 2[\mathrm{I}>2 \sigma(\mathrm{I})]$ & $0.0275,0.0628$ & $0.0459,0.0811$ & $0.0175,0.0393$ & $0.0205,0.0475$ \\
\hline $\mathrm{R} 1, w \mathrm{R} 2$ (all data) & $0.0375,0.0703$ & $0.0848,0.0946$ & $0.0205,0.0405$ & $0.0234,0.0483$ \\
\hline Largest diff. peak, hole $\left[\mathrm{e}^{-3}\right]$ & $0.788,-0.418$ & $1.256,-1.777$ & $0.374,-0.382$ & $1.101,-1.112$ \\
\hline
\end{tabular}


Elemental analysis (\%) for $\mathrm{C}_{24} \mathrm{H}_{40} \mathrm{~N}_{4} \mathrm{O}_{4} \mathrm{Sb}_{2} \mathrm{O}$ : Calculated: C 31.86, H 4.46, N 6.19, Found: C 31.88, H 4.45, N 6.21.

Synthesis of 4: THF (20 mL) was condensed on to a mixture of $\left(\left[\left(\mathrm{CH}_{2}\right)_{2}\{\mathrm{~N}(\mathrm{H}) \mathrm{C}(\mathrm{Me}) \mathrm{CHC}(\mathrm{Me})=\mathrm{O}\}_{2}\right]\right)$ ( $3 \mathrm{mmol}, 0.672 \mathrm{~g}$ ) and $\mathrm{BiCl}_{3}(2 \mathrm{mmol}, 0.630 \mathrm{~g})$ at $-196{ }^{\circ} \mathrm{C}$. The reaction mixture was stirred at room temperature for $12 \mathrm{~h}$. The resultant turbid reaction mixture was filtered and layered with $n$-pentane resulting in crystals of $4(0.07 \mathrm{~g}, 76 \%)$. ${ }^{1} \mathrm{H}$ NMR $\left(500 \mathrm{MHz}, \mathrm{THF}-\mathrm{D}_{8}\right): \delta 1.87\left(\mathrm{~s}, 6 \mathrm{H}, \mathrm{CH}_{3} \mathrm{CN}\right), \delta 1.89$ (s, $6 \mathrm{H}, \mathrm{CH}_{3} \mathrm{CO}$ ), $\delta 3.42$ (s(br), $4 \mathrm{H}, \mathrm{CH}_{2}$ ), $\delta 4.91$ (s, 2 $\mathrm{H}, \mathrm{CH}), \delta 10.93(\mathrm{~s}, 2 \mathrm{H}, \mathrm{NH}) \mathrm{ppm} ;{ }^{13} \mathrm{C} \mathrm{NMR}(126$ MHz, THF-D $\left.)_{8}\right): \delta 18.75\left(\mathrm{CH}_{3}\right), \delta 28.91\left(\mathrm{CH}_{3}\right), \delta 44.44$ $\left(\mathrm{CH}_{2}\right), \delta 96.15(\mathrm{CH}), \delta 163.57\left(\mathrm{CH}_{3} \mathrm{CN}\right), \delta 194.70$ $\left(\mathrm{CH}_{3} \mathrm{CO}\right)$ ppm; Elemental analysis $(\%)$ for $\mathrm{C}_{35} \mathrm{H}_{58-}$ $\mathrm{N}_{6} \mathrm{O}_{6} \mathrm{Bi}_{2} \mathrm{Cl}_{6}$ : Calculated: $\mathrm{C}$ 32.80, $\mathrm{H}$ 4.53, N 6.52, Found: C 32.79, H 4.56, N 6.54.

\section{Results and Discussion}

Based on our recent experience with $\beta$-ketoimine ligands in pnictogen coordination chemistry, ${ }^{11}$ we set out to employ this ligand system to prepare adducts of $\mathrm{SbCl}_{3}$ and $\mathrm{BiCl}_{3}$. Two $\beta$-ketoimine ligands, monofunctional $[\mathrm{O}=\mathrm{C}(\mathrm{Me})] \mathrm{CH}[\mathrm{C}(\mathrm{Me}) \mathrm{NHAr}](\mathbf{L 1})$ where $\mathrm{Ar}$ is 2,6-diisopropylphenyl and the bi-functional $\left[\left(\mathrm{CH}_{2}\right)_{2}\{\mathrm{~N}(\mathrm{H}) \mathrm{C}(\mathrm{Me}) \mathrm{CHC}(\mathrm{Me})=\mathrm{O}\}_{2}\right]$ (L2) were chosen in this study (Figure 1).

The reaction between equimolar quantities of $\mathrm{PnCl}_{3}$ ( $\mathrm{Pn}=\mathrm{Sb}, \mathrm{Bi})$ and $\mathbf{L} \mathbf{1}$ and subsequent crystallization of the reaction mixture from THF resulted in the isolation of analytically pure $\left[(\mathbf{L 1})(\mathrm{THF}) \mathrm{SbCl}_{3}\right]_{2} \quad$ (1) and $\left[(\mathbf{L 1})(\mathrm{THF}) \mathrm{BiCl}_{3}\right]_{2}$ (2). Compounds $\mathbf{1}$ and $\mathbf{2}$ were characterized by single-crystal X-ray diffraction experiments, NMR spectroscopy and elemental analysis. $\mathbf{1}$ crystallizes in the monoclinic crystal system with $\mathrm{P} 2{ }_{1} / \mathrm{c}$ space group while 2 crystallizes in the triclinic crystal system with space groupP $\overline{1}$. Solid-state structures of $\mathbf{1}$ and $\mathbf{2}$ provided in Figure 2 reveal that the pnictogen atoms in $\mathbf{1}$ and $\mathbf{2}$ possess a coordination number of six.

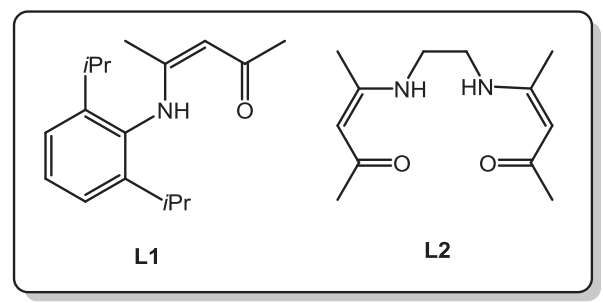

Figure 1. $\beta$-Ketoimine ligands used in the current study.
Analysis of bond lengths in $\mathbf{1}$ and $\mathbf{2}$ provide an insight into the bonding and Lewis acidity of $\mathrm{PnCl}_{3}$ The average $\mathrm{Sb}-\mathrm{Cl}$ and $\mathrm{Bi}-\mathrm{Cl}(\mathrm{Pn}-\mathrm{Cl} 1, \mathrm{Pn}-\mathrm{Cl} 2$ and $\mathrm{Pn}-\mathrm{Cl} 3$ ) distances in $\mathbf{1}$ and $\mathbf{2}$ are observed to be 2.408 and $2.565 \AA$, respectively. These values are close to the corresponding sum of the covalent radii of Pn and $\mathrm{Cl}$ atoms, $\sum \mathrm{r}_{\mathrm{cov}}(\mathrm{Sb} \& \mathrm{Cl})=2.41 \AA$ and $\sum \mathrm{r}_{\mathrm{cov}}(\mathrm{Bi} \&$ $\mathrm{Cl})=2.50 \AA .{ }^{12}$ Thus, the three $\mathrm{Pn}-\mathrm{Cl}$ interactions constitute the primary bonds. The three polarized $\mathrm{Pn}-$ $\mathrm{Cl}$ primary bonds concurrently give rise to three Lewis acidic interactions at sites trans to the $\mathrm{Pn}-\mathrm{Cl}$ bonds. These secondary interactions to the pnictogen atoms occur via the coordination of $\mathrm{O}$-atoms of $\mathbf{L} \mathbf{1}$ and one THF molecule and a chloride bridging with the neighbouring monomeric units. The average $\mathrm{Bi}-\mathrm{O}$ distance $(2.472 \AA)$ is shorter than the average $\mathrm{Sb}-\mathrm{O}$ distance $(2.586 \AA)$. Similarly, the bridging Pn-Cl1' bond lengths, $\mathrm{Bi}-\mathrm{Cl1}$ ' distance $(3.056 \AA$ ) is shorter than Sb-Cl1' distance (3.323 $\AA$ ). Higher Lewis acidity of $\mathrm{BiCl}_{3}$ draws the $\mathrm{O}$ - and $\mathrm{Cl}$-atoms closer to the bismuth center in the secondary coordination site in $\mathbf{2}$ as compared to $\mathbf{1}$.

To strengthen our inference on the higher Lewis acidity of $\mathrm{BiCl}_{3}$ over $\mathrm{SbCl}_{3}$, we further proceeded to synthesize the $\mathbf{L 2}$ adducts of $\mathrm{PnCl}_{3}$. We observed different ratios of $\mathrm{Pn}$ and $\mathbf{L} \mathbf{2}$ in respective adducts. When $\mathrm{PnCl}_{3}$ was treated with $\mathbf{L 2}$, we isolated $\left[\mathbf{L} 2 \mathrm{SbCl}_{3}\right]_{2}(\mathbf{3})$ and $\left[(\mathbf{L} 2)_{3}\left(\mathrm{BiCl}_{3}\right)_{2}\right]$ (4). NMR spectroscopy and elemental analysis of the crystallized samples of $\mathbf{3}$ and $\mathbf{4}$, initially confirmed their identity and purity. Solid-state structures of $\mathbf{3}$ and $\mathbf{4}$ were elucidated using single-crystal X-ray diffraction experiments. Both $\mathbf{3}$ and $\mathbf{4}$ crystallize in the triclinic crystal system with $\mathrm{P} \overline{1}$ space group. Their solid-state structures are represented in Figure 3. An initial glance at the structure of $\mathbf{3}$ reveals that $\mathrm{Sb}$ exhibits a coordination number of five and a distorted square pyramidal arrangement of donor atoms. The three $\mathrm{Sb}-$ $\mathrm{Cl}$ bonds form the primary bonds with an average distance of $2.4135 \AA$. Only two secondary interactions are observed in 3. $\mathrm{O} 1$ and $\mathrm{O} 2$ ' coordinate to the $\mathrm{Sb}$ atom at the secondary bonding sites trans to $\mathrm{Cl} 1$ and $\mathrm{Cl} 2$ respectively with an average distance of $2.502 \AA$. The secondary coordination site trans to $\mathrm{Cl} 3$ remains vacant, indicating that the energy of this orbital is too high for donor molecules to coordinate. In contrast to the structural features of $\mathbf{3}$, compound $\mathbf{4}$ possessing $\mathrm{Bi}$ atom exhibiting a coordination number of six with a slightly distorted octahedral geometry. The three primary $\mathrm{Bi}-\mathrm{Cl}$ bonds exhibit an average distance of $2.590 \AA$. Contrary to the observation in $\mathbf{3}$, three secondary interactions are observed at the bismuth center 


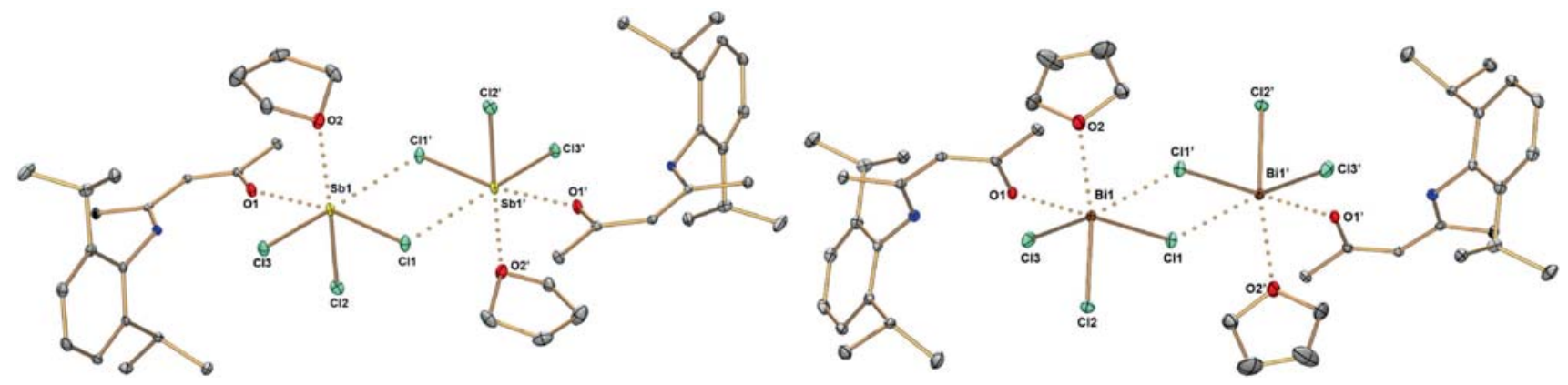

Figure 2. Solid state structures of 1 (left) and 2 (right). Hydrogen atoms are omitted for clarity. Selected bond lengths [Å] and angles $\left[{ }^{\circ}\right]$ in 1: Sb1-O1 2.411(2), Sb1-O2 2.761(3), Sb1-Cl1 2.4720(9), Sb1-Cl2 2.384(1), Sb1-Cl3 2.3681(8), O1Sb1-Cl1 99.80(6), O1-Sb1-Cl3 80.23(6), Cl3-Sb1-Cl1 91.28(3), Cl2-Sb1-O2 175.21(6). Selected bond lengths [A] and

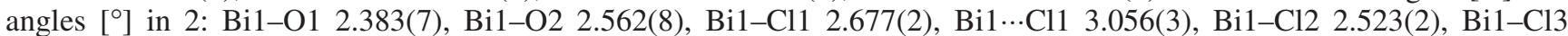
2.496(3), Cl1-Bi1-O1 103.0(1), O1-Bi1-Cl3 83.0(2), Cl3-Bi1-Cl1 91.07(8), Cl2-Bi1-O2 169.0(2).
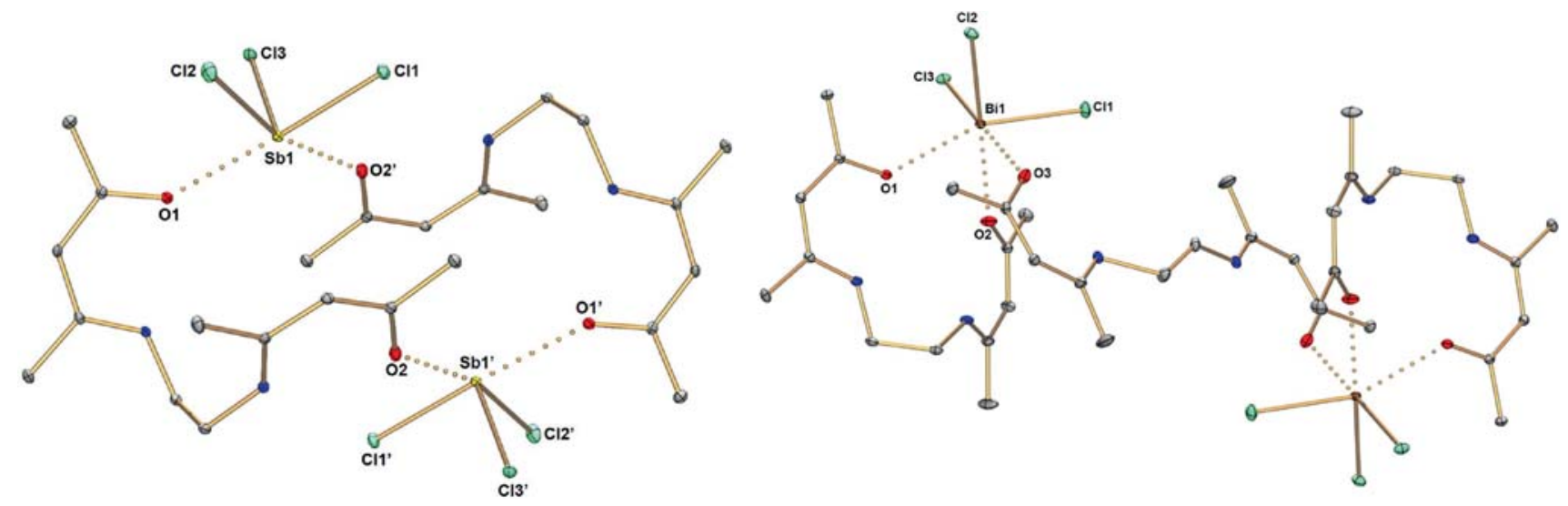

Figure 3. Solid state structures of 3 (top) and 4 (bottom). Hydrogen atoms are omitted for clarity. Selected bond lengths $[\AA]$ and angles $\left[{ }^{\circ}\right]$ in 3: Sb1-O1 2.584(2), Sb1-O2 2.420(2), Sb1-Cl1 2.4310(7), Sb1-Cl2 2.4549(7), Sb1-Cl3 2.3546(6), O1-Sb1-Cl2 90.67(4), O1-Sb1-O2 102.95(6), Cl2-Sb1-Cl1 88.96(2), Cl3-Sb1-O1 84.22(4), Cl3-Sb1-O2 82.77(4). Selected bond lengths $[\AA]$ and angles $\left[{ }^{\circ}\right]$ in 4: Bi1-O1 2.551(3), Bi1-O2 2.476(3), Bi1-O3 2.453(4), Bi1-Cl1 2.580(1), Bi1-Cl2 2.599(1), Bi1-Cl3 2.593(1), Cl2-Bi1-O1 100.86(7), O1-Bi1-O2 72.8(1), Cl2-Bi1-Cl1 96.82(4), Cl1-Bi1-O2 87.57(9), Cl3-Bi1-O3 172.6(1).

trans to $\mathrm{Cl} 1, \mathrm{Cl} 2$ and $\mathrm{Cl} 3$. The three $\mathrm{O}$-atoms bind to the bismuth center with an average $\mathrm{Bi}-\mathrm{O}$ distance of $2.493 \AA$. The higher coordination number at $\mathrm{Bi}$ in $\mathbf{4}$ as compared to $\mathrm{Sb}$ in $\mathbf{3}$ is strong evidence for the higher Lewis acidity exhibited by $\mathrm{BiCl}_{3}$ as compared to $\mathrm{SbCl}_{3}$.

Having evidenced higher Lewis acidity in $\mathrm{BiCl}_{3}$ in comparison to $\mathrm{SbCl}_{3}$ in the solid-state, we went on to probe the Lewis acidity of the heavier pnictogen chloride in solution. We used a modified GutmannBeckett method to quantify the Lewis acidity of $\mathrm{SbCl}_{3}$ and $\mathrm{BiCl}_{3}$ in solution. ${ }^{13}$ This method has been traditionally applied to electron-deficient boron compounds, ${ }^{14}$ it has been recently applied in the Lewis acid chemistry of heavier main group elements. ${ }^{3,4,15} \mathrm{In}$ this test, triethyl phosphine oxide (TEPO) is used as a basic probe to quantify the Lewis acids using ${ }^{31} \mathrm{P}$ NMR spectroscopy. A solution of TEPO in $\mathrm{CD}_{2} \mathrm{Cl}_{2}$ shows a single sharp peak at $\delta 50.6 \mathrm{ppm}$ in the ${ }^{31} \mathrm{P}$ NMR spectrum. When this solution was treated with eight equivalents of $\mathrm{SbCl}_{3}$, the peak shifted to $\delta 73.8 \mathrm{ppm}$, indicating a de-shielded phosphorus signal as a result of binding of TEPO to the Lewis acidic $\mathrm{SbCl}_{3}$ (Figure 4). Treating the free TEPO solution in $\mathrm{CD}_{2} \mathrm{Cl}_{2}$ with eight equivalents of $\mathrm{BiCl}_{3}$ shifted the free TEPO signal in the ${ }^{31} \mathrm{P}$ NMR to $\delta 78.0 \mathrm{ppm}$. From this observation, it is clear that $\mathrm{BiCl}_{3}$ de-shields the ${ }^{31} \mathrm{P}$ NMR signal more than $\mathrm{SbCl}_{3}$ thus proving that the former is more Lewis acidic than the latter.

\section{Conclusions}

$\beta$-Ketoimine adducts of $\mathrm{SbCl}_{3}$ and $\mathrm{BiCl}_{3}$ were successfully synthesized and well-characterized. Solidstate structural analysis indicates that the secondary 


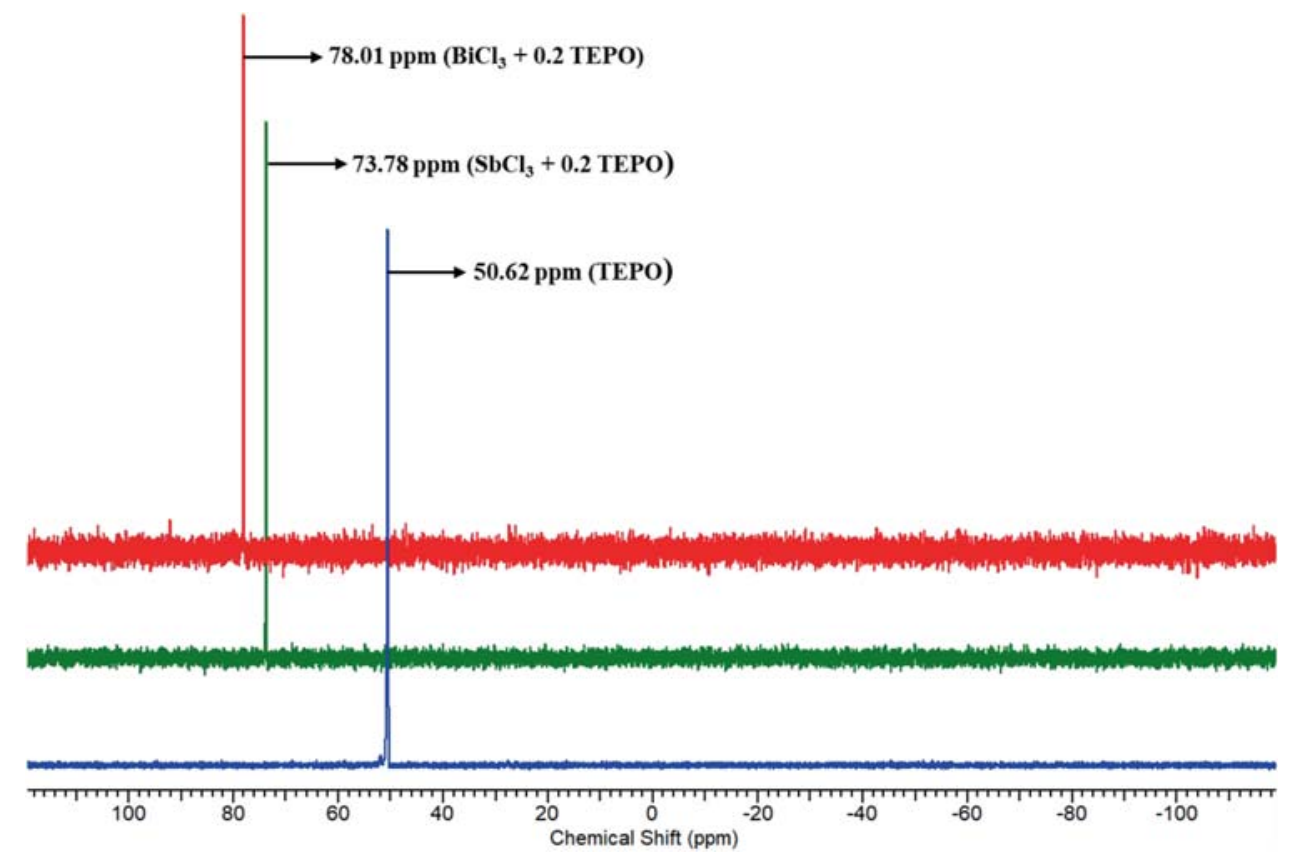

Figure 4. ${ }^{31} \mathrm{P}$ NMR spectra of TEPO, $\left(\mathrm{SbCl}_{3}+0.2 \mathrm{TEPO}\right)$ and $\left(\mathrm{BiCl}_{3}+0.2 \mathrm{TEPO}\right)$ recorded in $\mathrm{CD}_{2} \mathrm{Cl}_{2}$.

bonding is stronger in $\mathrm{BiCl}_{3}$ in comparison to $\mathrm{SbCl}_{3}$. Gutmann-Beckett test reveals that $\mathrm{BiCl}_{3}$ de-shields the phosphorus signal of triethylphosphine oxide in ${ }^{31} \mathrm{P}$ NMR spectrum more than $\mathrm{SbCl}_{3}$. The solid-state and solution studies conclude that $\mathrm{BiCl}_{3}$ is more Lewis acidic than $\mathrm{SbCl}_{3}$.

\section{Acknowledgements}

We thank the Council of Scientific and Industrial Research (Grant Number: 01(2777)/14/EMR-II) for the generous funding. Alex P. Andrews is thanked for X-ray diffraction experiments.

\section{References}

1. (a) Ollevier T $2013 \mathrm{New}$ trends in bismuth-catalyzed synthetic transformations Org. Biomol. Chem. 11 2740; (b) Bothwell J M, Scott W, Krabbe S W and Mohan R S 2011 Applications of bismuth(III) compounds in organic synthesis Chem. Soc. Rev. 404649

2. Norman N C 1994 Coordination chemistry of antimony and bismuth: Lewis acidity, $\sigma *$-orbitals and coordination geometry Phosph. Sulfur Silicon Relat. Elem. 87 167

3. Kannan R, Kumar S, Andrews A P, Jemmis E D and Venugopal A 2017 Consequence of Ligand bite angle on bismuth Lewis acidity Inorg. Chem. 569391

4. Balasubramaniam S, Kumar S, Andrews A P, Varghese B, Jemmis E D and Venugopal A 2019 A dicationic bismuth(III) Lewis acid: catalytic hydrosilylation of olefins Eur. J. Inorg. Chem. 3265
5. Balasubramaniam S, Varghese B and Venugopal A 2019 Bismuth(III) dication trapped on a chlorobismuthate J. Coord. Chem. 721417

6. (a) Chitnis S S, Vos K A, Burford N, McDonald R and Ferguson M J 2016 Distinction between coordination and phosphine ligand oxidation: interactions of di- and triphosphines with $\mathrm{Pn}^{3+}(\mathrm{Pn}=\mathrm{P}, \mathrm{As}, \mathrm{Sb}, \mathrm{Bi})$ Chem. Commun. 52 685; (b) Chitnis S S, Robertson A P M, Burford N, Patrick B O, McDonald R and Ferguson M J 2015 Bipyridine complexes of $\mathrm{E}^{3+}(\mathrm{E}=\mathrm{P}, \mathrm{As}, \mathrm{Sb}, \mathrm{Bi})$ : strong Lewis acids, sources of $\mathrm{E}(\mathrm{OTf})_{3}$ and synthons for $\mathrm{E}^{\mathrm{P}}$ and $\mathrm{E}^{\mathrm{V}}$ cations Chem. Sci. 6 6545; (c) Robertson A P M, Burford N, Gray P A and Ferguson R 2014 Interpnictogen cations: exploring new vistas in coordination chemistry Angew. Chem. Int. Ed. 53 6050; (d) Chitnis S S, Burford N, Decken A and Ferguson M J 2013 Coordination complexes of bismuth triflates with tetrahydrofuran and diphosphine ligands Inorg. Chem. 527242

7. (a) Beckett M A, Strickland G C, Holland J R and Varma K S 1996 A convenient n.m.r. method for the measurement of Lewis acidity at boron centres: correlation of reaction rates of Lewis acid initiated epoxide polymerizations with Lewis acidity Polymer 37 4629; (b) Mayer U, Gutmann V and Gerger W 1975 The acceptor number-A quantitative empirical parameter for the electrophilic properties of solvents Monatsh. Chem. 1061235

8. Everett Jr G W and Holm R H 1965 The synthesis and proton resonance study of the solution equilibria of bis( $\beta$-ketoamino) nickel(II) complexes J. Am. Chem. Soc. 872117

9. Gogoi S, Bhuyan R and Barua N C 2005 Iodine-catalyzed conversion of $\beta$-dicarbonyl compounds into $\beta$ enaminones within a minute under solvent-free conditions Synth. Commun. 352811 
10. (a) Altomare A, Cascarano G, Giacovazzo C and Guagliardi A 1994 J. Appl. Crystallogr. 27 435; (b) Sheldrick G M 2008 A short history of SHELX Acta Cryst. A64 112

11. Johnson J A, Ashokan A, Chalana A K, Andrews A P and Venugopal A 2017 Neutral and cationic $\beta$-ketoiminato bismuth complexes Z. Anorg. Allg. Chem. 643607

12. Cordero B, Gomez V, Platero-prats A E, Rev M, Echeverr J, Cremades E, Barrag F and Alverez S 2008 Covalent radii revisited Dalton Trans. 2832

13. Adamczyk-wozniak A, Jakubczyk M, Sporzyński A and Żukowska G 2011 Quantitative determination of the Lewis acidity of phenylboronic catechol estersPromising anion receptors for polymer electrolytes Inorg. Chem. Commun. 141753
14. Sivaev I B and Bregadze V I 2014 C-H Bond activation of arenes by $\left[8,8^{\prime}-\mu-\mathrm{I}-3,3^{\prime}-\mathrm{Co}\left(1,2-\mathrm{C}_{2} \mathrm{~B}_{9} \mathrm{H}_{10}\right)_{2}\right]$ in the presence of sterically hindered Lewis bases Coord. Chem. Rev. 270-271 75

15. (a) Tsao F A, Waked A E, Cao L, Hofmann J, Liu L, Grimme S and Stephan D W 2016 S(VI) Lewis acids: fluorosulfoxonium cations Chem. Commun. 52 12418; (b) Großekappenberg H, Reißmann M, Schmidtmann M and Müller T 2015 Quantitative assessment of the Lewis acidity of silylium ions Organometallics 34 4952; (c) Pan B and Gabbaï F P $2014\left[\mathrm{Sb}\left(\mathrm{C}_{6} \mathrm{~F}_{5}\right) 4\right]\left[\mathrm{B}\left(\mathrm{C}_{6} \mathrm{~F}_{5}\right)_{4}\right]$ : An air stable, Lewis acidic stibonium salt that activates strong elementfluorine bonds J. Am. Chem. Soc. 136 9564; (d) Caputo C B, Hounjet L J, Dobrovetsky R and Stephan D W 2013 Lewis acidity of organofluorophosphonium salts: hydrodefluorination by a saturated acceptor Science 3411374 